\title{
Productivity of a Portable Winch System Used in Salvage Logging of Storm-Damaged Timber
}

\author{
Ebru Bilici, Güryay Volkan Andiç, Abdullah Emin Akay, John Sessions
}

\begin{abstract}
Storm damages result in serious losses in many regions, primarily by stem breakage or blowdown. Extraction of storm-damaged trees often requires more difficult than normal skidding activities due to obstacles created during the storm. In this study, the productivity of a portable winch was evaluated as a possible alternative to recover storm-damaged timber. Field measurements were conducted in the Alabarda Forest Enterprise Chief located near the city of Kütahya in western Turkey, where storm damage often occurs during the winter season. The time study was implemented in two slope classes (35\% and 55\%) and two skidding distances $(40 \mathrm{~m}$ and $60 \mathrm{~m})$. All timber was skidded uphill. A regression mode was developed that related productivity to log volume, ground slope and skidding distance. The highest percentage of total cycle time was observed for skidding logs to the landing. The highest productivity $\left(3.96 \mathrm{~m}^{3} /\right.$ hour $)$ was found at the shorter skidding distance $(40 \mathrm{~m})$ and the lower ground slope (35\%). Statistical analyses indicated that productivity was most highly affected by log volume, followed by skidding distance and ground slope. Larger log loads increased productivity, while both longer skidding distances and steeper slopes reduced productivity.
\end{abstract}

Keywords: salvage logging, storm damage, portable winch, productivity

\section{Introduction}

Forest fires, winter storms, avalanches, and droughts may lead to significant biological and ecological damages to forest vegetation. Storm damage is considered one of the most harmful abiotic factors in many regions of the world (Lorz et al. 2010). As a result of storm incidents, forestry activities become even more costly and dangerous in damaged stands and in some cases the forest management plan needs to be revised. Expansion of openings within the forested areas increases the risk of weed invasion, insect damage, and forest fires (Çanakçığlu 1993).

In order to properly handle the aftermath of storm damage, salvage logging operations should be conducted quickly before the trees deteriorate, which may cause additional impacts on the forest ecosystem and lead to value loss for timber products (Taş 2017). However, recovery of storm-damaged timber is considered one of the most difficult, dangerous, and costly forest operations (Akay and Taş 2017). Thus, logging operations in storm-damaged stands should be well planned, considering not only economic factors, but also ecological and ergonomic factors.

Planning and implementation of proper logging operations is an important issue for sustainability of the forest ecosystem, protection of residual trees in the stands and soil conservation (Akay et al. 2007). Unsuitable logging operations potentially cause long term impacts on residual trees, saplings, and forest soil (Eroğlu 2012). One of the key points in developing a proper logging plan is to select the right equipment by considering tree size, terrain conditions, and machine specifications (Bilici et al. 2018). Extraordinary situations, such as salvage logging operations, require different planning strategies than regular planning due to potential technical problems and safety issues that need to be addressed in the extraordinary situations. These include storm-damaged trees blocking access roads, culverts, and ditches, dangerous leaning trees, 
uprooted trees under stress, broken trees, and tangled piles of trees.

Compared with human or animal-powered manual logging systems, mechanized logging systems employing mechanical forest harvesting equipment are more suitable for storm-damaged stands since these systems are safer for the worker and highly productive (Andiç 2018). In Turkey, skidding logs by farm tractor is a widely used method. On the other hand, several studies suggested that ground-based skidding of logs using a portable winch system may be a solution in logging operations where farm tractors are not appropriate for economic, ecological, or worker safety (Akay et al. 2014, Gülci et al. 2015). The portable winch system provides an acceptable production rate, while minimizing damages to residual stands and surface soil (Gülci et al. 2017). This system is usually integrated with a skidding cone, which improves the system performance by reducing ground friction and decreasing the risk of hanging logs on obstacles, which reduces the skidding time and increases productivity (Acar 2016). Also, the use of a skidding cone significantly reduces the damage to residual trees (Britto et al. 2017).

Although some previous studies (Akay et al. 2014, Gülci et al. 2015, Acar 2016, Gülci et al. 2017) focused on the performance of the portable winch system in logging operations, no study could be identified that investigated the productivity of the portable winch system in salvage logging of storm-damaged timber. The purpose of this study is to evaluate the productivity of the portable winch system used in extraction of timber after a winter storm. In the study, productivity of the portable winch was determined by using the time study method, while considering the effects of ground slope and skidding distance.

\section{Materials and Methods}

\subsection{Study Area}

The study area was selected from the border of the Tavşanlı Forest Enterprise Directorate (FED) in the city of Kütahya in Turkey. The study was implemented during logging operations in the Alabarda Forest Enterprise Chief (FEC) within the borders of Tavşanlı FED (Fig. 1). The study area is located between $28^{\circ} 56^{\prime} 41^{\prime \prime}$ $-29^{\circ} 50^{\prime} 05^{\prime \prime}$ East longitude and $39^{\circ} 21^{\prime} 10^{\prime \prime}-39^{\circ} 46^{\prime} 56^{\prime \prime}$ North latitude. The area was mostly covered by Pinus brutia and Pinus nigra stands. The average elevation and ground slope are $900 \mathrm{~m}$ and $25 \%$, respectively.

Alabarda FEC was selected as the study area because of intense storm damage in winter 2015 and because a large volume of storm-damaged timber was

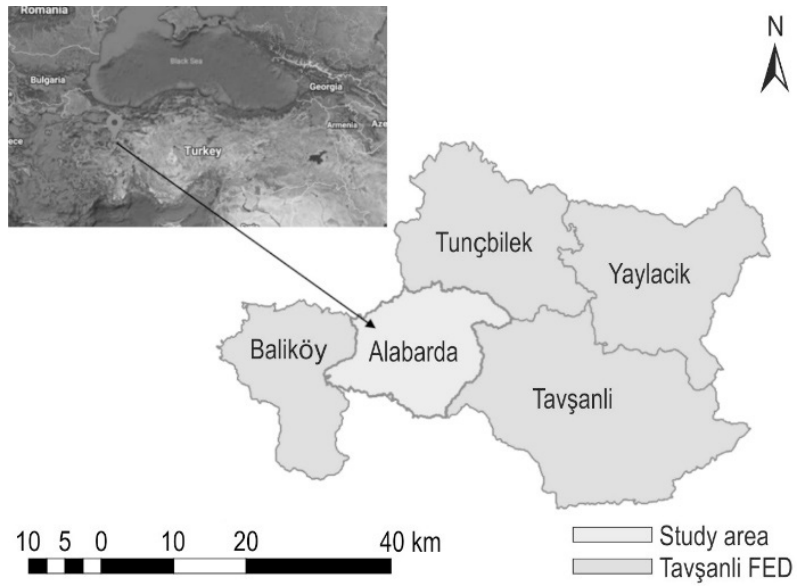

Fig. 1 Location of the study area in Alabarda FEC

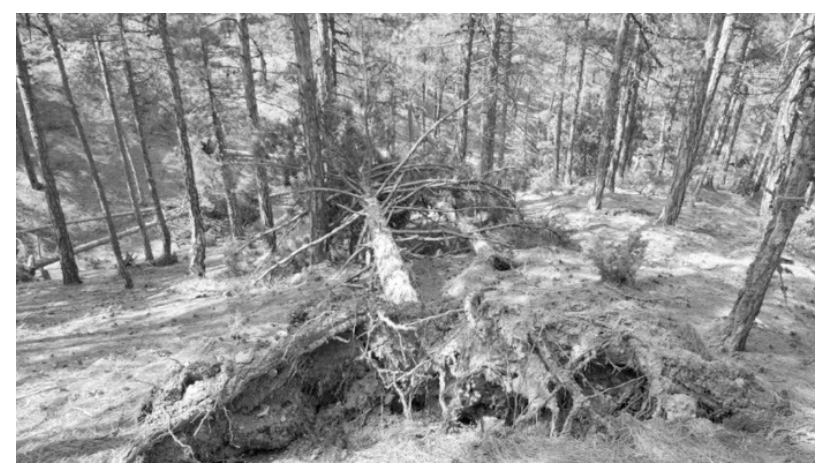

Fig. 2 Storm-damaged and overturned trees in the study area (Photo by G.V. Andiç)

scheduled for extraction from this area (Fig. 2). FEC estimated about $197208 \mathrm{~m}^{3}$ of timber would be recovered by salvage logging operations. The data was collected during a cut-to-length logging operation, which was conducted on dry surface in a dry weather condition in April 2016.

\subsection{Productivity Analysis}

Productivity of the portable winch was evaluated as an economical and practical logging method to extract salvage timber uphill after the winter storm damage. The portable winch, with Honda GXH-50cc engine, is able to pull up to a $1000 \mathrm{~kg}$ load with a single rope (Fig. 3). The specifications of the portable winch are presented in Table 1. For proper operation, portable winch was attached on an anchor tree at the landing area close to the roadside for a fan shaped setting. The system is equipped with synthetic rope, chain choker ( $1.5 \mathrm{~m})$, polyester choker $(2 \mathrm{~m})$, metal locks and hooks. The logging operation was conducted by a choker-setter in the woods and a winch operator. 


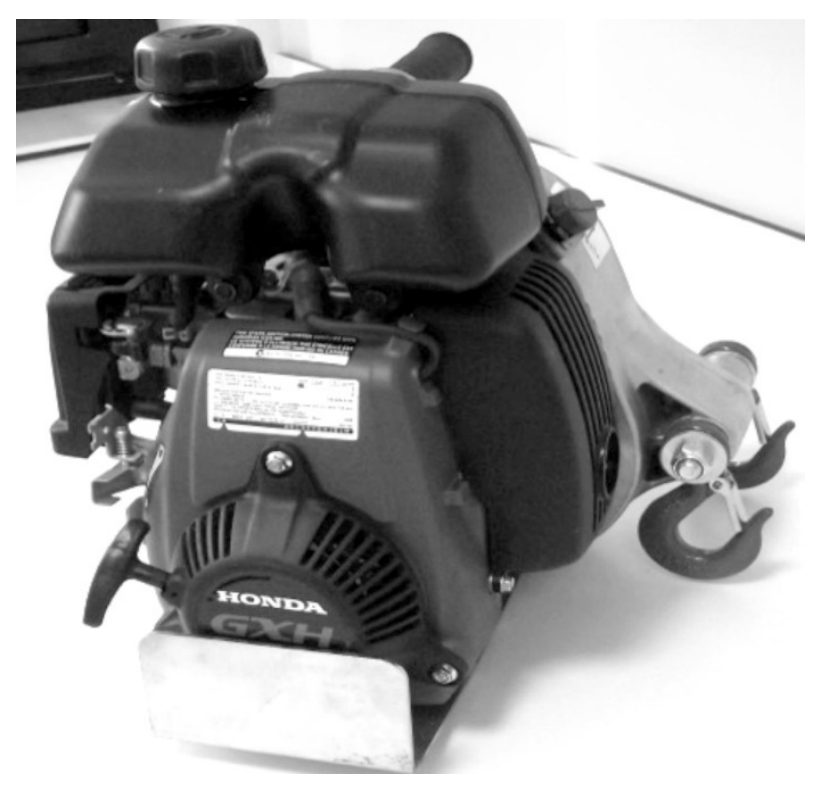

Fig. 3 Gasoline-powered portable winch

Table 1 Technical characteristics of portable winch

\begin{tabular}{|l|c|}
\hline \multicolumn{1}{|c|}{ Properties } & Values \\
\hline Motor & $\begin{array}{l}\text { Four-stroke engine } \\
\text { (Honda GXH-50cc) }\end{array}$ \\
\hline Weight & $16 \mathrm{~kg}$ \\
\hline Maximum Pulling Power (single) & $1000 \mathrm{~kg}$ \\
\hline Maximum Pulling Power (double) & $2000 \mathrm{~kg}$ \\
\hline Minimum rope diameter & $10 \mathrm{~mm}$ \\
\hline Maximum rope diameter & $20 \mathrm{~mm}$ \\
\hline
\end{tabular}

The time standard of work should be calculated correctly in order to maintain the productivity of the operation and to prevent wage unfairness among the loggers. Therefore, it is of great importance to conduct time studies of logging operations (Eker et al. 2014). The productivity of the portable winch system was derived using time study analysis of the salvage logging operation (Spinelli and Magagnotti 2011). The duration of each work stage in the work cycle of portable winch skidding was determined at the office based on images that were captured with a video camera in the field (Fig. 4). Video images of portable winch skidding were taken for two slope classes (35\% and $55 \%$ ) and two skidding distances ( $40 \mathrm{~m}$ and $60 \mathrm{~m}$ ). The time measurements were repeated for 30 cycles for each class with a total of 120 cycles.

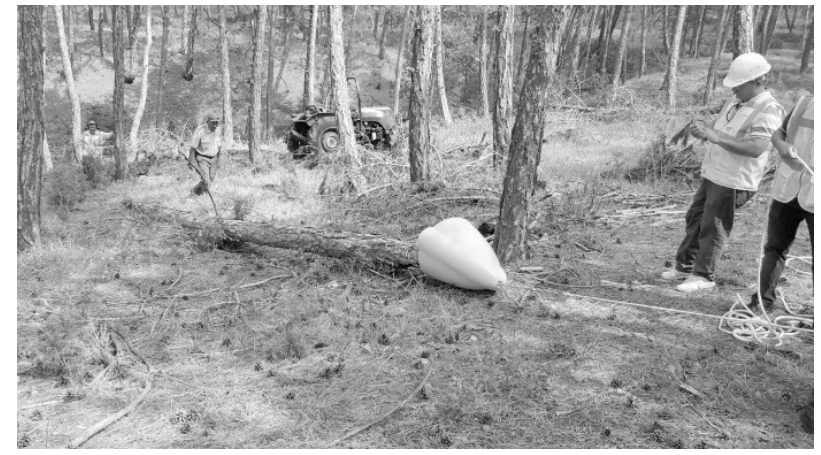

Fig. 4 Salvage logging of storm-damaged timber by portable winch with skidding cone

The main work stages in the work cycle were:

$\Rightarrow$ carrying the choker and skidding cone from landing to stump

$\Rightarrow$ choker setting at the stump

$\Rightarrow$ skidding logs from stump to landing area

$\Rightarrow$ releasing logs from chokers at the landing.

Delay time due to hang-ups of logs on stumps and other obstacles were also included in the time measurements. The diameter and length of logs were measured to compute timber volume skidded in each cycle. Then, productivity per productive machine hour $(\mathrm{PMH})$ of the portable winch system for each cycle was computed based on total cycle time and timber volume:

Where:

$$
p=\frac{v}{t} * 60
$$

$p$ productivity, $\mathrm{m}^{3} / \mathrm{PMH}$

$v$ total timber volume, $\mathrm{m}^{3}$

$t$ cycle time, minutes.

\subsection{Statistical Analysis}

First, average values were calculated for log size (i.e. diameter, length, and volume), duration of work stages, total cycle time, and productivity during the logging operation. To investigate the relations between variable factors (i.e. slope, distance, and volume) and productivity of the logging operation, a Pearson Correlation test was made at the $99 \%$ confidence level. Then, linear regression was used to search for the effects of variable factors on productivity.

The effects of different timber volumes on productivity were investigated using One-Way ANOVA at a 0.05 significance level. For this purpose, the log volumes per cycle were divided into three classes including low $\left(<0.20 \mathrm{~m}^{3}\right)$, medium $\left(0.20-0.24 \mathrm{~m}^{3}\right)$, and high $\left(>0.24 \mathrm{~m}^{3}\right)$. Using the Independent Samples Test, we 
also investigated whether there was a significant difference in productivity of the portable winch system within the slope classes (35\% and $55 \%$ ) and within distance classes $(40 \mathrm{~m}$ and $60 \mathrm{~m}$ ). The SPSS 16.0 statistical software package was used for all statistical analyses.

\section{Results and Discussion}

The measurements of salvaged timber extracted by portable winch were recorded for slope classes and skidding distance classes in the field. The average values of log diameter, log length, and timber volume are presented in Table 2. The average timber volume per cycle was very similar for all slope and distance classes (i.e. $0.23-0.24 \mathrm{~m}^{3}$ ). To investigate the effects of different timber volumes on productivity, volumes were divided into three classes: low $\left(<0.20 \mathrm{~m}^{3}\right)$, medium $\left(0.20-0.24 \mathrm{~m}^{3}\right)$, and high $\left(>0.24 \mathrm{~m}^{3}\right)$.

For all combinations of slope and distance classes, the average time spent on each work stage is listed in Table 3. In all combinations, the work stage with the highest time consumption was skidding logs from

Table 2 The average values of log sizes obtained in the field

\begin{tabular}{|c|c|c|c|c|c|}
\hline$\frac{\ddot{\circ}}{\infty}$ & 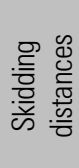 & & 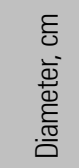 & $\begin{array}{l}E \\
\text { ह் } \\
\bar{\Xi} \\
\bar{\Xi}\end{array}$ & $\begin{array}{l}\stackrel{m}{E} \\
\Phi^{\prime} \\
\frac{\text { है }}{\rho}\end{array}$ \\
\hline \multirow{8}{*}{$35 \%$} & \multirow{4}{*}{$40 \mathrm{~m}$} & Min. & 19.00 & 3.00 & 0.18 \\
\hline & & Max. & 33.00 & 4.00 & 0.34 \\
\hline & & Ave. & 21.84 & 3.24 & 0.23 \\
\hline & & STD. & 3.36 & 0.43 & 0.05 \\
\hline & \multirow{4}{*}{$60 \mathrm{~m}$} & Min. & 19.00 & 3.00 & 0.18 \\
\hline & & Max. & 35.00 & 4.00 & 0.38 \\
\hline & & Ave. & 21.85 & 3.21 & 0.24 \\
\hline & & STD. & 3.68 & 0.42 & 0.06 \\
\hline \multirow{8}{*}{$55 \%$} & \multirow{4}{*}{$40 \mathrm{~m}$} & Min. & 19.00 & 3.00 & 0.18 \\
\hline & & Max. & 33.00 & 4.00 & 0.34 \\
\hline & & Ave. & 21.84 & 3.21 & 0.24 \\
\hline & & STD. & 2.99 & 0.41 & 0.05 \\
\hline & \multirow{4}{*}{$60 \mathrm{~m}$} & Min. & 19.00 & 3.00 & 0.18 \\
\hline & & Max. & 36.00 & 4.00 & 0.41 \\
\hline & & Ave. & 21.83 & 3.23 & 0.24 \\
\hline & & STD. & 3.60 & 0.43 & 0.06 \\
\hline
\end{tabular}

stump to landing, followed by the work stage of carrying the choker and skidding cone from landing to stump. Delay time due to hang-ups of logs to stumps and other obstacles was the third most time consuming activity in total cycle time. When keeping the skidding distance constant for the combinations, the total cycle time of the skidding operation increased as the ground slope increased. Akay et al. (2014) also reported that total cycle time of skidding by portable winch increased as uphill ground slope increased.

The productivity of timber logging operations is closely related to total cycle time and average timber volume transported in a cycle. When the timber volume is about constant in each cycle, total cycle time can be defined as the only factor that affects the hourly productivity. In this study, increasing ground slope or skidding distance increased the total cycle time, which then led to reduced productivity. The results indicated that the highest productivity $\left(3.96 \mathrm{~m}^{3} /\right.$ hour $)$ of the portable winch was observed at the shorter skidding distance $(40 \mathrm{~m})$ and the lower ground slope $(35 \%)$, while the productivity was the lowest $\left(2.91 \mathrm{~m}^{3} /\right.$ hour $)$ at the longer skidding distance and the higher ground slope. Gülci (2014) reported that the average productivity of the portable winch was $4.45 \mathrm{~m}^{3} /$ hour in a study where the average skidding distance, ground slope, and volume per cycle was $40 \mathrm{~m}, 40 \%$, and $0.20 \mathrm{~m}^{3}$, respectively. It was assumed that the average productivity in salvage logging operation was lower than in regular logging operation due to the existence of extra obstacles on the ground such as debris and pieces of dead trees.

A Pearson Correlation test was used to search whether there is a statistical relationship between variable factors (i.e. slope, distance, and volume) and productivity of the portable winch system. As a result of the correlation analysis, it was found that there was a statistically significant and negative correlation between the productivity and the variable factors of slope and distance $(p=<.0010)$. However, the relationship between the productivity and log volume was statistically significant and in positive direction $(p<.001)$. Related studies also reported that the slope and the skidding distance affect adversely the productivity of the portable winch system, while increasing timber volume has positive effects on productivity (Gülci 2014, Sert 2014, Gülci et al. 2017). After correlation analysis, a regression model was developed to indicate the effects of independent variables on productivity (Table 4).

The reliability of the model was evaluated according to the Tolerance value and VIF value. The regression model, in which the dependent variable $(Y)$ 
Table 3 Values obtained by measurement

\begin{tabular}{|c|c|c|c|c|c|c|c|c|c|c|}
\hline$\frac{\bigotimes}{\text { 음 }}$ & 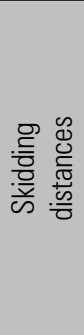 & & 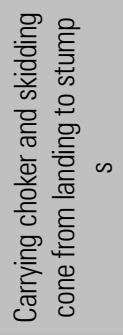 & 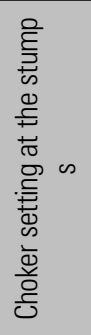 & 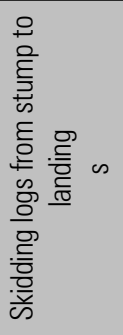 & 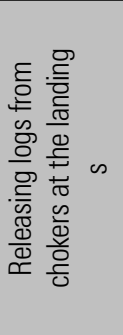 & 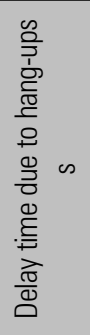 & 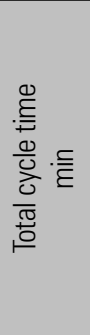 & 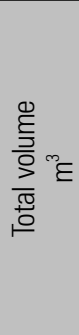 & 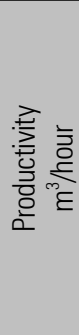 \\
\hline \multirow{8}{*}{$35 \%$} & \multirow{4}{*}{$40 \mathrm{~m}$} & Min. & 34.00 & 9.00 & 122.00 & 6.00 & 20.00 & 2.90 & 0.18 & 3.53 \\
\hline & & Max. & 38.00 & 13.00 & 137.00 & 9.00 & 31.00 & 3.60 & 0.34 & 6.36 \\
\hline & & Ave. & 36.23 & 10.73 & 130.07 & 7.37 & 24.75 & 3.13 & 0.23 & 4.44 \\
\hline & & STD. & 1.19 & 1.14 & 3.19 & 0.67 & 4.65 & 0.18 & 0.05 & 0.75 \\
\hline & \multirow{4}{*}{$60 \mathrm{~m}$} & Min. & 44.00 & 9.00 & 171.00 & 7.00 & 28.00 & 3.93 & 0.18 & 2.66 \\
\hline & & Max. & 51.00 & 13.00 & 184.00 & 9.00 & 33.00 & 4.68 & 0.38 & 5.05 \\
\hline & & Ave. & 47.50 & 11.23 & 177.97 & 7.93 & 29.67 & 4.18 & 0.24 & 3.39 \\
\hline & & STD. & 1.91 & 0.94 & 3.37 & 0.83 & 2.07 & 0.20 & 0.06 & 0.66 \\
\hline \multirow{8}{*}{$55 \%$} & \multirow{4}{*}{$40 \mathrm{~m}$} & Min. & 36.00 & 10.00 & 133.00 & 7.00 & 25.00 & 3.20 & 0.18 & 3.24 \\
\hline & & Max. & 41.00 & 15.00 & 144.00 & 11.00 & 30.00 & 3.97 & 0.34 & 5.55 \\
\hline & & Ave. & 37.33 & 12.93 & 139.97 & 8.53 & 27.71 & 3.42 & 0.24 & 4.12 \\
\hline & & STD. & 1.12 & 1.20 & 2.27 & 0.90 & 2.14 & 0.21 & 0.05 & 0.62 \\
\hline & \multirow{4}{*}{$60 \mathrm{~m}$} & Min. & 53.00 & 10.00 & 185.00 & 7.00 & 20.00 & 4.32 & 0.18 & 2.47 \\
\hline & & Max. & 58.00 & 16.00 & 202.00 & 12.00 & 33.00 & 5.20 & 0.41 & 4.70 \\
\hline & & Ave. & 54.50 & 13.70 & 193.23 & 9.70 & 27.50 & 4.64 & 0.24 & 3.08 \\
\hline & & STD. & 1.28 & 1.49 & 4.22 & 1.29 & 4.00 & 0.26 & 0.06 & 0.60 \\
\hline
\end{tabular}

Table 4 The summary table of the Pearson correlation test

\begin{tabular}{|l|c|c|c|c|c|}
\hline & & Productivity & Slope & Distance & Volume \\
\hline \multirow{4}{*}{$\begin{array}{l}\text { Pearson } \\
\text { correlation }\end{array}$} & Productivity & 1.000 & -0.371 & -0.534 & 0.685 \\
\cline { 2 - 6 } & Slope & -0.371 & 1.000 & 0.000 & 0.002 \\
\cline { 2 - 6 } & Distance & -0.534 & 0.000 & 1.000 & 0.070 \\
\cline { 2 - 6 } & Volume & 0.685 & 0.002 & 0.070 & 1.000 \\
\hline \multirow{4}{*}{$\begin{array}{l}\text { Sig. } \\
\text { (1-tailed) }\end{array}$} & Productivity &. & 0.000 & 0.000 & 0.000 \\
\cline { 2 - 6 } & Slope & 0.000 &. & 0.500 & 0.493 \\
\cline { 2 - 6 } & Distance & 0.000 & 0.500 &. & 0.225 \\
\cline { 2 - 6 } & Volume & 0.000 & 0.493 & 0.225 &. \\
\hline
\end{tabular}

indicates the productivity and independent variables affect productivity, is shown in Eq. 2. The regression model provided statistically significant results at the confidence level of $99 \%\left(p<.001, R^{2}=0.947\right)$.

$$
Y=4.343-0.031 X_{1}-0.048 X_{2}+14.045 X_{3}
$$

Where:

$Y$ productivity, $\mathrm{m}^{3} / \mathrm{hr}$

$X_{1}$ ground slope, $\%$

$\mathrm{X}_{2}$ slope distance, $\mathrm{m}$

$X_{3} \log$ volume, $\mathrm{m}^{3}$.

In the following stage, One-Way ANOVA was used as a parametric test to examine the effects of different timber volume classes (low, medium, and high) on the productivity. Table 6 indicates that the average productivity of the portable winch system tends to increase as the timber volume increases. As a result of the analysis of variance, a statistically significant difference was found between volume classes with $F=47.13$ and $p<0.05$ (Table 7). The Tukey test was used to determine the source of the difference. The results indicated that there was a significant difference between low-medium, low-high and medium-high volume classes. 
Table 5 Regression model table

\begin{tabular}{|c|c|c|c|c|c|c|c|c|}
\hline & \multirow{2}{*}{ Model } & \multicolumn{2}{|c|}{ Unstandardized coefficients } & \multirow{2}{*}{$\frac{\text { Standardized coefficients }}{\text { Beta }}$} & \multirow{2}{*}{$t$} & \multirow{2}{*}{$p$-value } & \multicolumn{2}{|c|}{ Collinearity statistics } \\
\hline & & $B$ & Std. Error & & & & Tolerance & VIF \\
\hline \multirow{4}{*}{1} & Constant & 4.343 & 0.147 & & 29.455 & 0.001 & & \\
\hline & Slope, $X_{1}$ & -0.031 & 0.002 & -0.373 & -17.498 & 0.001 & 1.000 & 1.000 \\
\hline & Distance, $X_{2}$ & -0.048 & 0.002 & -0.584 & -27.379 & 0.001 & 0.995 & 1.005 \\
\hline & Volume, $X_{3}$ & 14.045 & 0.413 & 0.726 & 34.012 & 0.001 & 0.995 & 1.005 \\
\hline
\end{tabular}

a - Dependent variable: Productivity

Table 6 The average productivity $\left(\mathrm{m}^{3} /\right.$ hour) of the portable winch for three volume classes

\begin{tabular}{|l|c|c|c|c|}
\hline & Volume classes & $N$ & Average & Std. deviation \\
\hline \multirow{3}{*}{ Productivity } & Low & 41 & 3.18 & 0.501 \\
\cline { 2 - 5 } & Medium & 32 & 3.48 & 0.541 \\
\cline { 2 - 5 } & High & 47 & 4.45 & 0.786 \\
\hline
\end{tabular}

Table 7 Results of ANOVA analysis

\begin{tabular}{|l|c|c|c|c|c|}
\hline & Sum of Squares & d.f. & Mean Square & $F$ & $p$ \\
\hline Between Groups & 38.292 & 2 & 19.15 & 47.13 & $<.001$ \\
\hline Within Groups & 47.530 & 117 & 0.41 & & \\
\hline Total & 85.822 & 119 & & & \\
\hline
\end{tabular}

At the final stage, an independent samples t-test was used to investigate whether there was a significant difference in productivity of the portable winch system within the slope classes and distance classes. As a result of the independent samples t-tests for slope classes, $p$ (Sig.) value was found to be less than .001, which means that there was a significant difference between the classes (Table 8).

The effect size $(d)$ of slope classes on productivity can be calculated as $d=t / N$ and the effect size is very large if $d>1$, large if $0.8<d<1$, moderate if $0.5<d<0.8$, and small if $0.2<d<0.5$ (Cohen 1988). The analysis of the slope effect on productivity showed that the effect size was 0.56 , which suggested that the effect of slope was of moderate size.

There was also a significant difference $(p<.001)$ in productivity between the skidding distance classes ac-

Table 8 Summary table of independent samples $t$-test

\begin{tabular}{|c|c|c|c|c|c|c|c|c|c|}
\hline & \multicolumn{2}{|c|}{$\begin{array}{l}\text { Levene's test for } \\
\text { equality of variances }\end{array}$} & \multicolumn{7}{|c|}{$t$-test for Equality of Means } \\
\hline & \multirow[t]{2}{*}{$F$} & \multirow[t]{2}{*}{ Sig. } & \multirow[t]{2}{*}{$t$} & \multirow{2}{*}{ d.f. } & \multirow{2}{*}{$\begin{array}{l}p \text {-value } \\
2 \text {-tailed }\end{array}$} & \multirow{2}{*}{$\begin{array}{c}\text { Mean } \\
\text { difference }\end{array}$} & \multirow{2}{*}{$\begin{array}{l}\text { Std. error } \\
\text { difference }\end{array}$} & \multicolumn{2}{|c|}{$\begin{array}{l}95 \% \text { confidence interva } \\
\text { of the difference }\end{array}$} \\
\hline & & & & & & & & Upper & Lower \\
\hline Equal variances assumed & 0.701 & 0.404 & 4.345 & 118.00 & 0.001 & 0.610 & 0.140 & 0.332 & 0.888 \\
\hline Equal variances not assumed & & & 4.345 & 116.83 & 0.001 & 0.610 & 0.140 & 0.332 & 0.888 \\
\hline
\end{tabular}

Table 9 Result of Independent Samples t-test

\begin{tabular}{|c|c|c|c|c|c|c|c|c|c|}
\hline & \multicolumn{2}{|c|}{$\begin{array}{l}\text { Levene's test for } \\
\text { equality of variances }\end{array}$} & \multicolumn{7}{|c|}{$t$-test for Equality of Means } \\
\hline & \multirow{2}{*}{$F$} & \multirow{2}{*}{ Sig. } & \multirow[t]{2}{*}{$t$} & \multirow{2}{*}{ d.f. } & \multirow{2}{*}{$\begin{array}{l}p \text {-value } \\
\text { 2-tailed }\end{array}$} & \multirow{2}{*}{$\begin{array}{c}\text { Mean } \\
\text { difference }\end{array}$} & \multirow{2}{*}{$\begin{array}{l}\text { Std. error } \\
\text { difference }\end{array}$} & \multicolumn{2}{|c|}{$\begin{array}{l}\text { 95\% Confidence interval } \\
\text { of the difference }\end{array}$} \\
\hline & & & & & & & & Upper & Lower \\
\hline Equal variances assumed & 2.499 & 0.117 & 6.858 & 118 & $<.001$ & 0.877 & 0.128 & 0.624 & 1.130 \\
\hline Equal variances not assumed & & & 6.858 & 112.57 & $<.001$ & 0.877 & 0.128 & 0.624 & 1.131 \\
\hline
\end{tabular}


cording to the results of independent samples $t$-tests (Table 9). The effect size (d) was calculated as 0.88 in terms of skidding distance effect on productivity. Thus, the effect of skidding distance was within the range of large size.

\section{Conclusions}

Winter storms cause serious damage to forest stands and result in economic and ecological losses in many regions of Turkey. In order to ensure sustainable management of forest resources, damaged trees should be extracted from the forest in the shortest time possible. However, salvage logging of storm damaged timber is more difficult and time consuming than regular logging operations. Therefore, alternative logging methods should be evaluated for use in stormdamaged stands. In this study, productivity of a portable winch system was evaluated as an alternative logging method in salvage logging operations. Time study analysis revealed that skidding logs from stump to landing was the largest time consuming work stage, followed by carrying the choker and skidding cone from landing to stump. Statistical analysis indicated that the productivity of the portable winch system increases as the timber volume hauled in each cycle increases. When the timber volume skidded was very similar in each cycle, increasing ground slope or skidding distance increased the total cycle time, which then resulted in significant reduction in productivity. The use of the portable winch system can be an efficient and safer alternative in storm-damaged areas compared to traditional manual methods.

The analysis of the portable winch presented in this study can be improved in future studies using additional slope classes and longer skidding distances. In addition, the portable winch system integrated with snatch blocks should be studied to investigate how manoeuvring the winch load around obstacles affects productivity and to determine potential ecological effects of the system.

\section{Acknowledgements}

This research was financially supported by Bursa Technical University Research Project (PN: BTU 171L15).

\section{References}

Acar, H.H., 2016: Log pulling sliding head to be used during cable skidding by drummed tractor. Proceedings of the $49^{\text {th }}$ FORMEC symposium, Gendek A., Moskalik T. (eds.), 4-7
September, Warsaw University of Life Sciences, Warsaw, Poland, 23-25 p.

Akay, A.E., Yuksel, A., Reis, M., Tutus, A., 2007: The impacts of ground-based logging equipment on forest soil. Pol. J. Environ. Stud. 16(3): 371-376.

Akay, A.E., Sert, M., Gülci, N., 2014: Evaluating productivity of mobile winch system used in logging operation on gentle ground slope. $2^{\text {nd }}$ National Forest and Environment Symposium, 22-24 October, Isparta, Turkey, 22-24 p.

Akay, A.E., Taş, İ., 2017: Developing a harvesting plan for forested areas under the risk of winter storm damage. Bulletin of the Transilvania University of Brasov 10(59): 11-18.

Andiç, G.V., 2018: Productivity analysis of portable winch system used in logging operations after storm damage. Master thesis, Bursa Technical University, Bursa, Turkey, 42 p.

Bilici, E., Akay, A.E., Abbas, D., 2018: Assessing the effects of site factors on the productivity of a feller buncher: a time and motion analysis. J. For. Res. 30(4): 1471-1478. https://doi. org/10.1007/s11676-018-0696-4

Britto, P.C., Jaeger, D., Hoffmann, S., Robert, R.C.G., Fantini, A.C., Vibrans, A.C., 2017: Productivity assessment of timber harvesting techniques for supporting sustainable forest management of secondary Atlantic Forest in southern Brazil. Ann. For. Res. 60(2): 203-215. https:// doi.org/10.15287/ afr.2017.898

Cohen, J., 1988: Statistical power analysis for the behavioural sciences ( $2^{\text {nd }}$ ed.). Hillsdale, NJ: Lawrence Earlbaum Associates, $490 \mathrm{p}$.

Çanakçıoğlu, H., 1993: Forest protection. İstanbul University Faculty of Forestry. Publication No: 3624/411. ISBN 975404-199-7. İstanbul, 633 p.

Eroğlu, H., 2012: Effects of different logging techniques on forest soil compaction at mountainous terrain. Kastamonu Üniversitesi Orman Fakültesi Dergisi 13(2): 213-225.

Eker, M., Acar, H., 2014: Assessment of Unit Work Time in Logging Operations. II. National Mediterranean Forest and Environment Symposium »The Future of Mediterranean Forests: Sustainable Society and Environment «, 22-24 October, Isparta, Turkey, 24-26 p.

Gulci, N., 2014: Researches on precision forestry in forest planning. PhD thesis, Kahramanmaraş Sütçü İmam University, Faculty of Forestry, Kahramanmaraş, Turkey, 264 p.

Gülci, N., Akay, A.E., Erdaş, O., Wing, M., Sessions, J., 2015: Planning optimum logging operations through precision forestry approaches, European Journal of Forest Engineering 1(2): 56-60.

Gülci, N., Yüksel, K., Akay, A.E., 2017: Productivity assessment of portable hand winch based skidding operation on snow cover. Kastamonu Üniversitesi Orman Fakültesi Dergisi 17(1): 124-131.

Lorz, C., Fürst, C., Galic, Z., Matijasic Podrazky, V., Potocic, N., Simoncic, P., Strauch, M., Vacik, H., Makeschin, F., 2010: 
GIS-based probability assessment of natural hazards in forested landscapes of Central and South-Eastern Europe. Environmental Management 46(6): 920-930. https://doi. org/10.1007/s00267-010-9508-0

Sert, M., 2014: Productivity and Ecological Evaluation of Mobile Winch System used in Logging Operations in Mountainous Regions. Master thesis, Kahramanmaraş Sütçü İmam University, Faculty of Forestry, Kahramanmaraş, Turkey, 82 p.
Spinelli, R., Magagnotti, N., 2011: The effects of introducing modern technology on the financial, labour and energy performance of forest operations in the Italian Alps. Forest Policy Econ 13(7): 520-524. https://doi.org/10.1016/j.forpol.2011.06.009

Taş, I., 2017: Developing the risk map of winter storm hazard using GIS based Fuzzy Logic method. Master thesis. Bursa Technical University, Faculty of Forestry, Bursa, Turkey, 79 p.

(C) 2018 by the authors. Submitted for possible open access publication under the terms and conditions of the Creative Commons Attribution (CC BY) license (http://creativecommons.org/licenses/by/4.0/).

Received: November 21, 2018

Accepted: February 07, 2019
Authors' addresses:

Assist. prof. Ebru Bilici, PhD*

e-mail: ebru.bilici@giresun.edu.tr

Giresun University

Dereli Vocational School

Forestry Department

28950 Giresun

TURKEY

Güryay Volkan Andiç, MSc.

e-mail: volkanandic@hotmail.com

Prof. Abdullah Emin Akay, PhD

e-mail: abdullah.akay@btu.edu.tr

Bursa Technical University

Faculty of Forestry

Forest Engineering Department

16310 Bursa

TURKEY

Prof. John Sessions, PhD.

e-mail: john.sessions@oregonstate.edu

Oregon State University

College of Forestry

FERM Department

Corvallis 97331, Oregon

USA

* Corresponding author 